Canadian Journal of Higher Education Revue canadienne d'enseignement supérieur

Volume 45, No. 4, 2015, pages $143-165$

\title{
Economic Benefits of Studying Economics in Canada: A Comparison of Wages of Economics Majors with Wages in Other Fields of Study, Circa 2005
}

Ather H. Akbari \& Yigit Aydede

Saint Mary's University

\begin{abstract}
We compared the wages of economics degree holders with of those in 49 other fields of study using data from the 2006 Canadian population census. At the undergraduate level, economics majors earned the sixth highest average wage in 2005. When demographic controls were applied, they ranked ninth on the salary scale. When we compared the wages in 15 fields that require students to take math courses, economists ranked in the middle, as they also did when working as managers and professionals. When working as business and finance professionals, economists had wages surpassed only by finance majors. At the graduate level, economics majors had a greater wage advantage over all of the other fields except for business majors. These results are useful for Canadian university economics departments that have been experiencing declining enrolments over the past few years. In addition, we hope they will enable students to make more informed choices regarding their academic discipline. The results also highlight the need to direct greater policy attention towards developing mathematical skills among incoming university students as a prerequisite for them to build analytical skills, the demand for which in the labour market has been demonstrated in some Canadian and US studies.
\end{abstract}

\section{Résumé}

En utilisant les données du recensement de la population canadienne de 2006, nous comparons les salaires de diplômés d'économie aux salaires de diplômés de 49 autres disciplines. Au niveau du premier cycle, le salaire moyen des titulaires d'un majeur en économie était le sixième salaire le plus élevé en 2005. Lorsqu'on applique des contrôles démographiques, cette cohorte se classe au 
neuvième rang de l'échelle salariale. En comparant les salaires de personnes ayant étudié dans un des 15 domaines obligeant les étudiants à suivre des cours de mathématiques, nous constatons que les économistes se classent dans le milieu, ce qui est aussi le cas lorsqu'ils travaillent comme gestionnaire ou professionnel. Lorsqu'ils travaillent en affaire ou en finance, les économistes ont un salaire qui n'est surpassé que par les professionnels qui ont terminé un majeur en finance. Pour les études aux cycles supérieurs, les titulaires d'un majeur en économie ont un plus grand avantage salarial par rapport aux autres disciplines, à l'exception des titulaires d'un majeur en affaire. Ces résultats sont utiles pour les départements d'économie des universités canadiennes qui ont connu des baisses au niveau des inscriptions au cours des dernières années. Nous espérons aussi que ces résultats permettent aux étudiants de faire des choix plus éclairés en ce qui a trait à leur discipline académique. Ces résultats mettent également en évidence la nécessité d'accorder une plus grande attention aux politiques de création de compétences en mathématiques chez les étudiants qui entrent à l'université. En fait, cela devrait être une condition préalable afin qu'ils perfectionnent leurs compétences analytiques, dont la demande sur le marché du travail a été démontrée dans des études canadiennes et américaines.

This paper provides an analysis of the labour-market performance of economics degree holders in Canada in relation to a cross-section of 49 other fields of study. We use microdata based on a $20 \%$ sample of the population, drawn from the 2006 Canadian population census.

Economics introduces students to tools that are fundamental to effective decision making in business, government, and everyday life. Yet, since the early 1990s, student enrolments in economics degree programs have fluctuated in Canada more than those in business and law degrees, whose graduates generally compete with economists in labour markets. ${ }^{1}$ Since 2003, student enrolments in economics have been falling. ${ }^{2}$

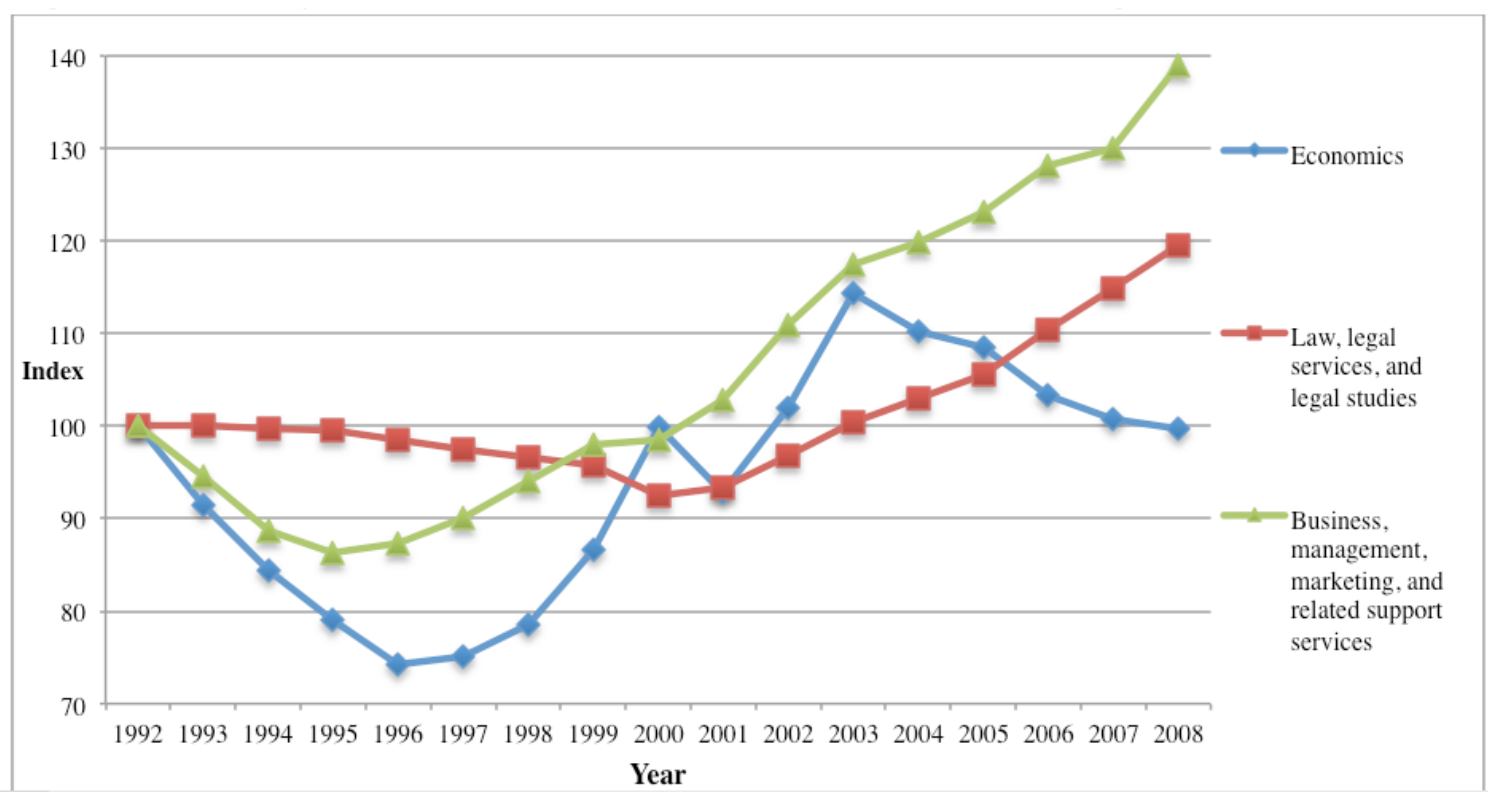

Figure 1. University enrolment trends: business, economics, and law degrees. 
Source: Statistics Canada Post-Secondary Student Information System (PSIS), annual survey, customized tabulations.

Notes: (1) Phased implementation of PSIS started in 2000. For the 2008/2009 collection year, PSIS covered $80 \%$ of public institutions. To the best of our knowledge, these data are comparable over time. For detailed information regarding the collection and quality of these data, please see http://www.statcan.gc.ca/cgi-bin/imdb/p2SV.pl?Function=getSurvey\&SDDS=5017\&lang=en\&db=imdb\& $\mathrm{adm}=8 \&$ dis=2. (2) In terms of Classification of Instructional Program levels, economics is at a four-digit classification level, while the other two are at a two-digit (i.e., broader) level.

Variations in student enrolments across fields of study may be attributed to several factors, including demographic factors, personal preferences, socioeconomic factors, or students' expectations of market rewards. ${ }^{3}$ Based on the Canadian National Survey of Graduate Students, Brahim and Montmarquette (2007) found that expected initial earning is an important determinant of a student's choice of a field of study.

Research investigating the delivery of economics curricula at universities in Australia, Canada, and the United States has found that in the post-World War II period, increasing emphasis has been placed on formalization in economics teaching, especially with the use of mathematics. The presence of mathematics in economics journal articles has grown significantly during this time (Espinosa, Rondon, \& Romero, 2012; Grubel \& Boland, 1986). As a result, classroom teaching has also become too mathematical and theoretical for most potential students, who may not discern its usefulness for productive work. An Australian study found that vocationally driven students, particularly females, could not readily see how an economics degree might lead to employment opportunities; the prevailing mindset of many students was that an economics degree did not increase job prospects as much as did a business degree (Millmow \& Bookallil, 2006). Hence, a comparative analysis of the labour-market outcomes of pursuing an economics degree is important, as it will enable students to (i) correctly understand the market value of learning economic tools of analysis and (ii) base their decisions on real labour-market data. A recent Ontario-focused Canadian study (Dion, 2014) that used data from the Programme for International Assessment of Adult Competencies (PIAAC) showed a decline in the numeracy skills of high-school graduates. This suggests that incoming university students may not be well prepared for the demands of university education, particularly in reference to mathematical requirements. ${ }^{4}$ Hence, an analysis of the labour-market outcomes of an economics education, which emphasizes mathematical tools of analysis, can provide important input for education policy-makers attempting to enhance numeracy skills at the pre-university level of education. This information will also be useful for university administrators, as declining public funding in Canada has made it important for them to respond to market demand (Snowdon, 2005). In addition, university faculty members who teach economics will find the information useful as they determine the demand for their research and the courses they teach; offering courses that will improve students' market rewards is desirable from an economic point of view. ${ }^{5}$ Finally, evidence of the financial benefits of studying economics is also important for economics departments that plan to expand their degree offerings. ${ }^{6}$

The methodology adopted in this paper is generally similar to that used by Black, Sanders, and Taylor (2003) in the United States. However, we also attempted to isolate the effects of motivation and ability, which are important unobservable characteristics of individuals. 


\section{Some Characteristics of the Data Used in This Study}

To use the 2006 census data for our study, we accessed the 20\% sample of microdata through Statistics Canada's Atlantic Research Data Centre at Dalhousie University. Special permission for this access was granted by Statistics Canada through the Social Sciences and Humanities Research Council (SSHRC). These data enabled the classification of individuals' highest postsecondary certificate, diploma, or degree by major fields of study. Statistics Canada classifies the major fields of study by using the Classification of Instructional Programs (CIP), which includes 1,375 instructional program classes that have finer breakdowns with up to six-digit codes. ${ }^{7}$ In order to avoid small sample sizes, we had to do some aggregation. We used the first two digits of the CIP codes to divide most of the 1,375 programs into various groups. For some business and social sciences majors, including economics, we used the first four digit levels of the CIP. After these aggregations, we were left with 50 degree programs, allowing the comparison of economics majors with majors in 49 other fields.

The overall sample was limited to full-time wage earners aged between 25 and 55 years, with no activity limitation, who had acquired a postsecondary degree in Canada. After these restrictions, the sample had 362,923 observations. The labour-market information collected for the 2006 census pertains to the year 2005. To provide a comparative overview of the overall labour-market performance of workers who had obtained university degrees in different fields of study, we report in Table 1 the unemployment rates and the average hourly wage rate earned by only full-time paid workers in each field. These data are organized by gender for those aged between 25 and 55 . Because these data are weighted, they reflect values for the entire population. They are also ranked in descending order of population wage rate in each field of study. We focus on comparing each field's hourly wage rate with the wage rate of economics majors.

As Table 1 shows, wage and unemployment rates vary dramatically by fields of studyfrom $\$ 21.30$ in the case of legal services to $\$ 46.34$ in finance, and a $1.94 \%$ unemployment rate in health services to $8.33 \%$ in precision production. The average wage rate is $\$ 33.75$ in the sample, and there are 19 fields of study, including economics, in which wage rates are higher than average. The top three wage earners are finance, law, and engineering majors. ${ }^{8}$ Economics majors are the sixth-highest wage earners but among the youngest in the sample, with only liberal arts and science graduates being younger. On average, those who earn less than economics majors make $24 \%$ less, while those who earn more than economics majors earn only $7.8 \%$ more. Overall, there is a weak but negative correlation between unemployment and wage rates. ${ }^{9} \mathrm{~A}$ striking finding in Table 1 is the similarity between the unemployment rates of economics majors and those of some science and technology majors (engineering, biological sciences, physical sciences, and mathematics). ${ }^{10}$ Except for a few majors, gender differences in unemployment rates and wages are significant: male workers have lower unemployment rates and higher average wage rates than female workers do. On average, $51.4 \%$ of employed workers are women; the lowest percentage (12.3\%) is in engineering, followed by aeronautics (17\%). The highest proportion of women in employment is in health services, which also has the lowest unemployment rate. There is some evidence of a negative correlation between gender composition of employment and wage rates. ${ }^{11}$ The most popular field of study among Canadian university degree holders is education, followed by engineering and business administration. Finance is among the least populated business majors. 


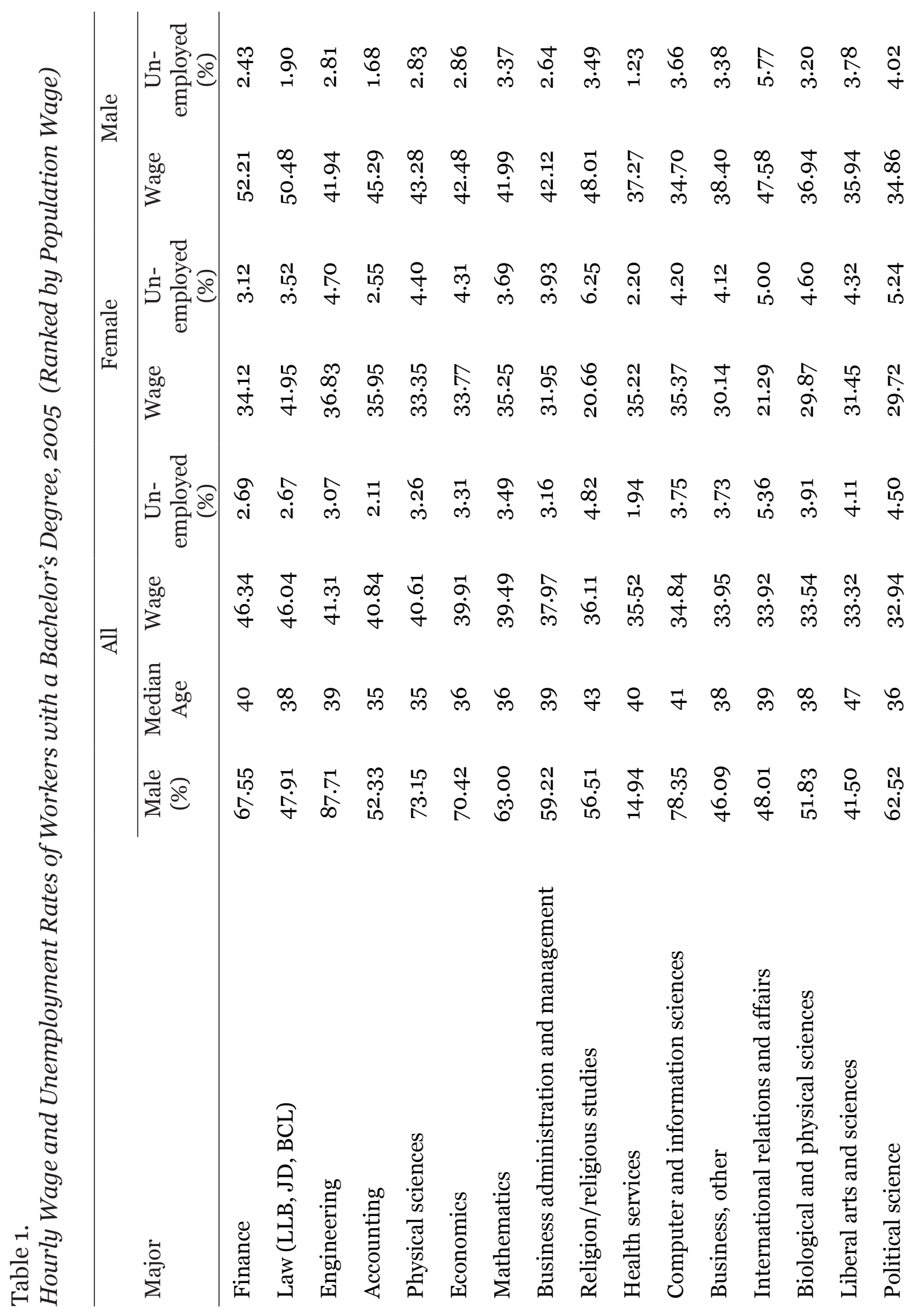


Economic Benefits of Studying Economics in Canada / A. H. Akbari \& Y. Aydede 148

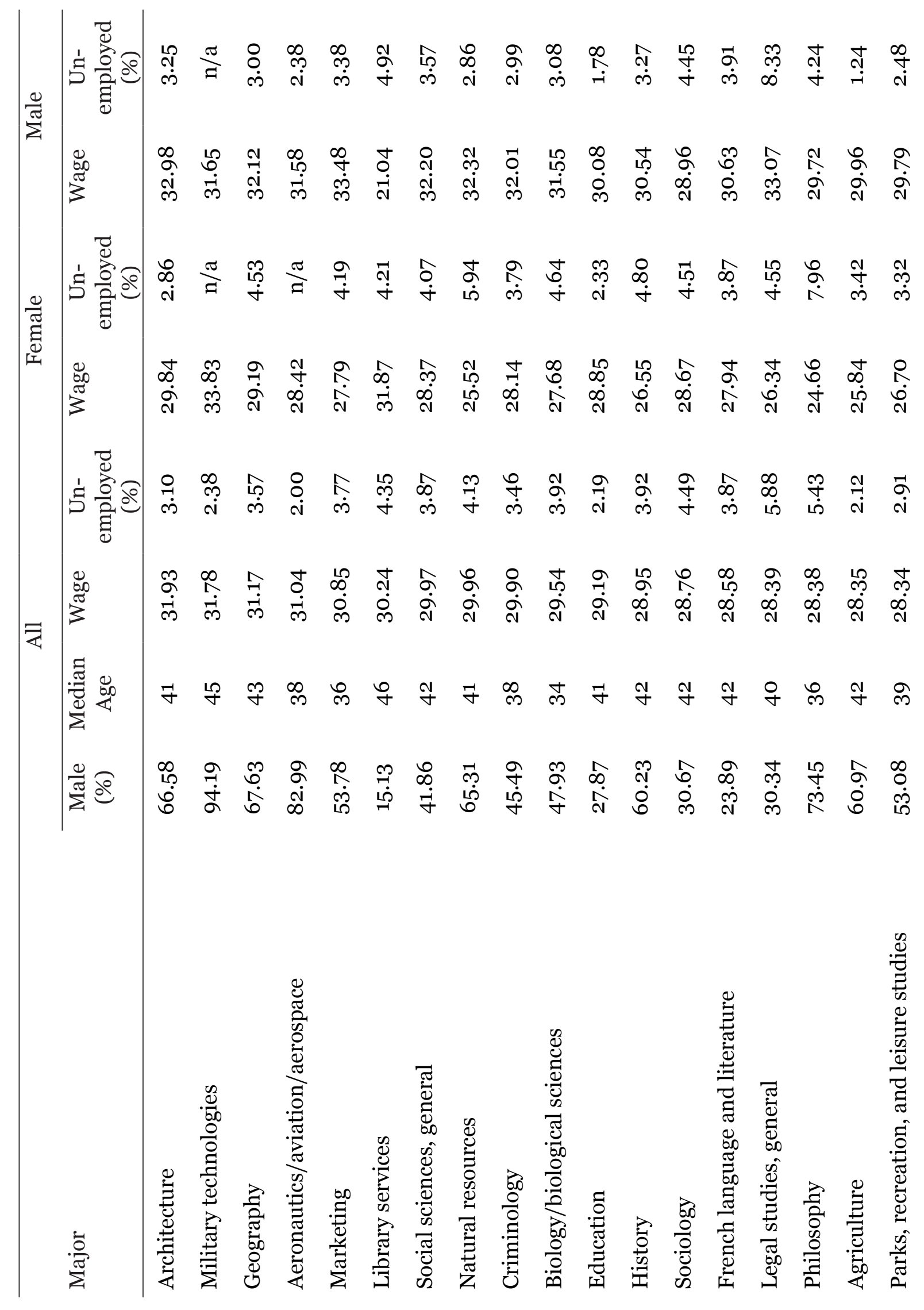




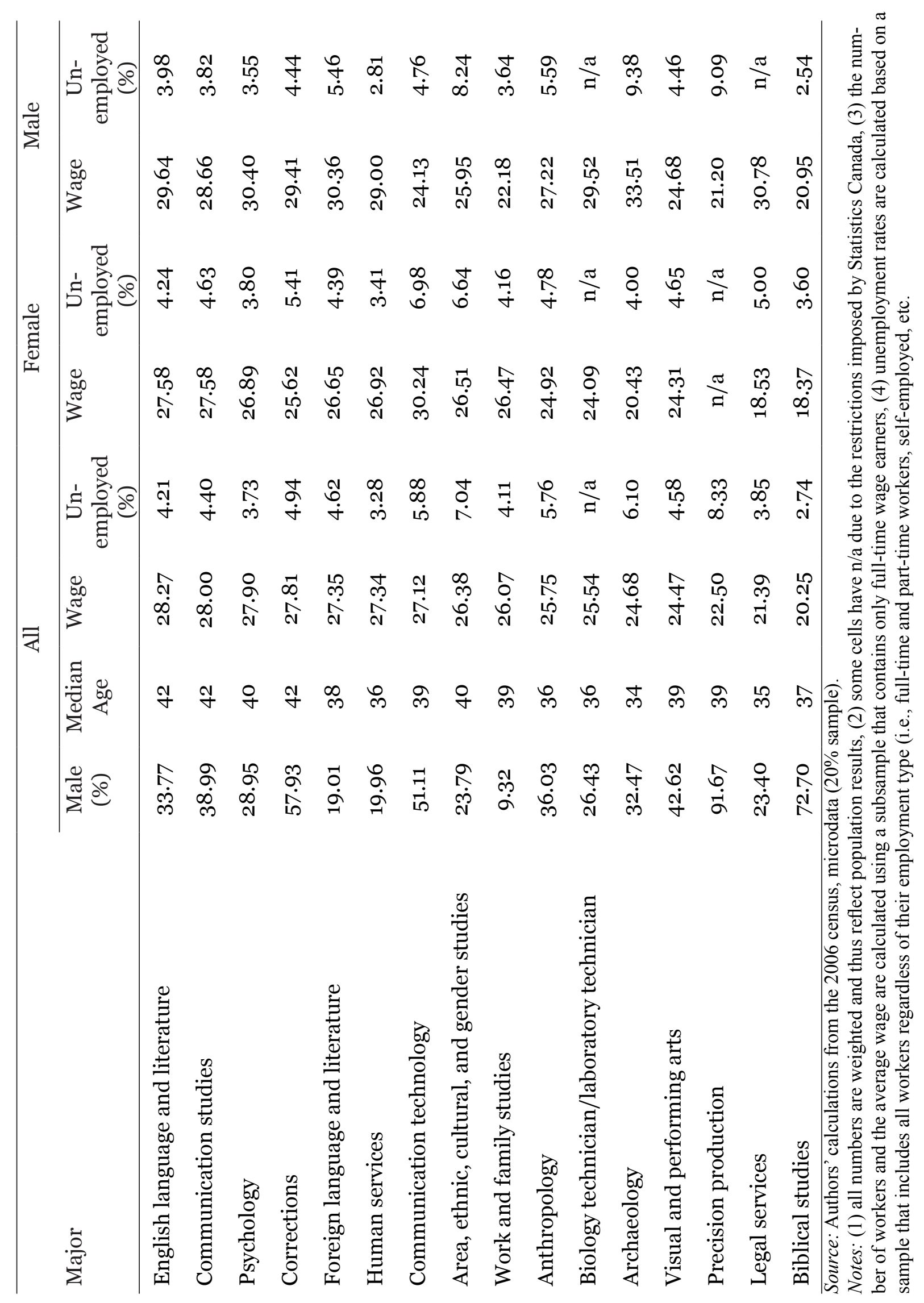


Those who major in economics earn less than those with majors in law or in some, but not all, business fields (such as accounting and finance). In contrast, the Australian study (Lewis, Daly, \& Fleming, 2004) found that those holding an economics degree in Australia earn more than those holding law or business degrees. ${ }^{12}$ Another study field complementary to economics is political science, whose graduates earn less than economics graduates and experience higher unemployment rates. ${ }^{13}$

\section{Comparing Earnings Across Study Fields, with Demographic Controls}

The above were general results. In order to draw meaningful comparisons between workers who earned their degrees in different academic fields, we must control for differences in their demographic compositions. In this section, we do so to compare the hourly wage rates of workers who hold an economics degree with workers who have obtained their degrees in other fields. Following Black et al. (2003), we organized our data into cells built on a set of demographic attributes (explained below) and estimated the following regression model:

$$
\ln \left(\mathrm{w}_{i}\right)-\ln \left(\overline{\mathrm{w}_{J}}\right)=\boldsymbol{\beta Z}+\varepsilon_{i},
$$

where $w_{i}$ is the wage of the person $i, \overline{\mathrm{w}}_{J}$ is the average wage of the cell $j$ built on a set of demographic attributes that the person $i$ possesses, $\mathbf{Z}$ is the vector of dummy variables for 49 majors (economics is the excluded major), $\beta$ is the vector of coefficients of interest, and $\varepsilon_{i}$ is the error term. The expression above demeans the wage (in natural logs) at each observation by taking the difference between a person's wage and the average wage of the cell to which that person belongs. Hence, $\boldsymbol{\beta}$ shows percentage differences between economics and other majors in terms of wages for workers with identical demographic characteristics.

As a common practice, we use the number of hours worked in the reference week-i.e., the week prior to census enumeration-as a proxy for the average hours worked per week during the year. Hence, the hourly wage is calculated as the total annual wage earned during the year, divided by the product of the number of weeks worked during the year and the number of hours worked in the reference week. To address a possible bias introduced due to this measure, a subsample comprised of workers who worked 52 weeks during the year and more than 35 hours in the reference week was also analyzed, in addition to weekly and annual average wages. The results for hourly wages and other measures did not differ substantially. Therefore, we only report results based on hourly wages. To control for differences in demographic characteristics across individuals in our sample, we organized our data into three cells defined by the number of variables used for demographic controls. Since our results were insensitive to cell definition, in Table 2 we report the results of only one cell, and we put the results of the other two cells in Appendix. In cell 1, we have controlled for the following characteristics: age, gender, visible minority, and immigration status. ${ }^{14}$ To avoid smaller cell sizes, we restrict the estimates to cells that have 150 or more members. ${ }^{15}$ As in Table 1 , we organized our Table 2 data in descending wage order. Finally, note that a negative number in Table 2 means that an average worker who declared the particular field of study as a major earned less than the one who declared economics as a major. A positive number means the opposite. 
Table 2.

Wage Differences Relative to Economics Major for Workers Aged 25 to 55 with Bachelor's Degree

\begin{tabular}{|c|c|c|}
\hline \multirow[b]{2}{*}{ Major } & \multicolumn{2}{|c|}{ Cell 1} \\
\hline & $\%$ & $t$ \\
\hline Engineering & 16.84 & 14.01 \\
\hline Finance & 13.87 & 7.13 \\
\hline Health services & 13.82 & 11.05 \\
\hline Law (LLB, JD, BCL) & 13.20 & $7 \cdot 44$ \\
\hline Accounting & 9.22 & 6.77 \\
\hline Computer and information sciences & 6.82 & 5.19 \\
\hline Mathematics & 5.83 & 2.86 \\
\hline Business administration and management & 2.98 & 2.46 \\
\hline Business, other & -0.02 & -0.01 \\
\hline Legal studies, general & -0.58 & -0.11 \\
\hline Physical sciences & -1.21 & -0.65 \\
\hline Criminology & -1.73 & -0.94 \\
\hline Military technologies & -2.60 & -0.39 \\
\hline Biological and physical sciences & -3.15 & -2.09 \\
\hline Marketing & -4.85 & -2.59 \\
\hline Natural resources & -7.83 & $-4 \cdot 57$ \\
\hline Education & $-7 \cdot 94$ & -6.90 \\
\hline Political science & -8.60 & $-5 \cdot 35$ \\
\hline Corrections & -9.17 & -2.27 \\
\hline Architecture & -10.28 & -5.28 \\
\hline Human services & -11.15 & -7.75 \\
\hline Communication studies & -11.35 & $-7 \cdot 35$ \\
\hline International relations and affairs & -12.53 & -2.00 \\
\hline Social sciences, general & -13.28 & $-5 \cdot 36$ \\
\hline Geography & -13.69 & -8.44 \\
\hline
\end{tabular}




\begin{tabular}{|c|c|c|}
\hline \multirow[b]{2}{*}{ Major } & \multicolumn{2}{|c|}{ Cell 1} \\
\hline & $\%$ & $t$ \\
\hline French language and literature & -14.29 & -6.06 \\
\hline Biology/biological sciences & $-14 \cdot 33$ & -9.48 \\
\hline Psychology & -15.00 & -11.25 \\
\hline Biology technician/laboratory technician & -15.06 & -1.23 \\
\hline Foreign language and literature & -15.14 & -8.03 \\
\hline Parks, recreation and leisure studies & -15.63 & -10.48 \\
\hline Sociology & $-15 \cdot 92$ & -10.41 \\
\hline Liberal arts and sciences & -16.42 & -10.27 \\
\hline Aeronautics/aviation/aerospace & -16.62 & -1.63 \\
\hline History & -16.97 & -11.03 \\
\hline Library services & -17.45 & -2.10 \\
\hline Area, ethnic, cultural, and gender studies & -17.55 & -6.29 \\
\hline Work and family studies & -17.88 & -7.95 \\
\hline English language and literature & -18.91 & -11.94 \\
\hline Agriculture & -19.44 & -9.77 \\
\hline Communication technology & -22.31 & $-4 \cdot 32$ \\
\hline Archaeology & -23.10 & -4.29 \\
\hline Philosophy & -23.44 & -7.94 \\
\hline Anthropology & -25.41 & -8.97 \\
\hline Visual and performing arts & -34.16 & -20.52 \\
\hline Religion/religious studies & -37.58 & -7.15 \\
\hline Legal services & -38.03 & -3.69 \\
\hline Precision production & $-43 \cdot 95$ & -3.15 \\
\hline Biblical studies & -53.29 & -24.15 \\
\hline
\end{tabular}

Notes: (1) The dependent variable is the natural log of the annual wage earned in the previous year, divided by the product of the number of weeks worked last year and the number of hours worked last week, demeaned at each cell point. (2) Standard errors are robust and adjusted by cell. (3) The number of observations is 204,222. (4) Economics is the excluded major. (5) The estimate is weighted to incorporate the sample stratification provided by the data.

(6) For the definition of cell 1, please see endnote 14 
A quick inspection of Table 2 shows that the demographic variables do appear to have influenced the results reported in Table 1. In general, workers with an undergraduate degree in economics fare very well when compared with others. In fact, for only eight majors out of 49 are the earnings higher than for economics majors. Those with degrees in mathematics, business administration and management, computer and information science, health services, and accounting whose earnings were lower than economists' in Table 1 earn more than economists after demographic controls are applied, while there is no statistically significant difference between economists' wages and the wages of those with physical science degrees, whose earnings were higher in Table 1. Engineers (who include chemical, civil, computer, electrical/electronics, and mechanical engineers) enjoy the highest wage premium over economists (16.84\%). Interestingly, unlike in Black et al.'s (2003) study, which used 1993 data for the United States, business majors (excluding those in marketing) earned higher average hourly wages than demographically comparable economics majors in Canada. Conversely, all majors in social sciences and humanities, such as history, political science, sociology, psychology, English literature, and philosophy, earn less than economics majors.

The above differences in labour-market earnings can be attributed to differences in demand and supply conditions in the labour market but also to differences in some unobservable characteristics of individuals, such as ability and motivation. In this paper, we try to isolate, indirectly, the effects of ability and motivation on labour-market earnings across disciplines by controlling for differences in their curricular requirements regarding mathematics courses, and by considering an individual's position in the organizational hierarchy. Our justification for this approach is based on particular surveys and studies conducted by professional organizations, government departments, and academicians, which we summarize below.

One survey of 789 business executives in the United States, conducted in 2013, showed that about $58 \%$ of businesses found analytical ability among their workers to be vital to their organizations and that this percentage was expected to grow to $82 \%$ over the next five years (American Management Association, 2013). The survey also considered quantitative skills to be important determinants of analytical skills. A British study on the demand for mathematical skills in the workplace identified five goals served by mathematical skills: improving efficiency, dealing with constant change and innovation, informing improvement, remaining competitive, and maintaining operations. The study also identified type of work, size of company, and position in the business cycle as factors likely to affect companies' particular mathematical needs (Hoyles, Wolf, Molyneux-Hodgson, \& Kent, 2002). A Canadian study (Hango, 2014) based on data obtained from the Programme for the International Assessment of Adult Competencies (PIAAC), found that Canadian-born university graduates with lower numeracy skills were eight percent less likely to be employed in a professional or managerial occupation than those with higher numeracy skills.

Finally, employees are better motivated when their work is given recognition within the organization. This recognition can be in the form of monetary reward, accolades, or promotion. In his blog, Broder (2013) recognizes worker motivation as important for productivity in an organization.

Different academic disciplines stress different analytical and mathematical abilities in students. This is reflected in their admission and curriculum requirements. Our survey of 
16 universities across Canada revealed mathematics as a common component of economics curricula. ${ }^{16}$ We also identified 11 other fields of study across all of the universities that require students to complete at least one course in mathematics. These fields include: accounting, biology, business administration, chemistry, computer sciences, engineering, finance, marketing, mathematics, medical laboratory, and physics. Requirements of mathematical courses vary not only across these fields but also within each field across Canadian universities. Hence, while we have tried to capture the similarities in terms of analytical skills across fields of study by considering their math requirements, we realize that the extent of the analytical skills developed in these fields may vary and could affect our results. Indeed, this issue could be the topic of another study. The present comparison is drawn from fields of study requiring any mathematical skills, as evidenced in there being a minimum of one mathematics course required in the curriculum.

The CIP codes for the academic disciplines reported in the 2006 census do not exactly match the above list, but we were able to identify the following 13 fields of study that closely match: accounting, biology/biological sciences, biological and physical sciences, biology technician/laboratory technician, business administration and management, business and others, computer and information sciences, engineering, finance, health services, marketing, mathematics, and physical sciences. Graduates of these fields may be considered somewhat comparable to economics graduates in terms of meeting the demand for mathematical skills in the workplace in Canada. ${ }^{17}$ Table 2 data reveal that the wages of graduates in six of these fields exceed the wages of economics graduates. In order of importance, engineering, finance, health services, and accounting graduates earn 9-17\% more, while those with business administration and management degrees earn only $2.7-3 \%$ more ${ }^{18}$ Among those with lower wages than economists, biology technicians, laboratory technicians, and biology/biological science majors earn 14-15\% lower wages, while the wages of those in physical sciences are only slightly lower (by 1.2\%). In summary, when we control for graduates' mathematical skills, graduates with an economics degree are valued somewhere in the middle in the Canadian labour market. ${ }^{19}$ However, the average dollar difference between economists' wages and the wages of graduates from these other disciplines is only about $\$ 2.22$.

We also attempted to control for motivational differences between workers by considering their position in the organizational hierarchy. Human Resources and Skills Development Canada (HRSDC) publishes an occupation matrix that identifies steps in the organizational hierarchy for each occupation..$^{20}$ The 2006 Canadian census codes are based on the HRSDC codes. From the occupational codes, we identified, within each field of study, graduates working in managerial and professional positions. In Table 3, we report their earning differences as compared with economists' (ranked in the first column). Data for business and finance professionals, reported in the same table, will be discussed later. To avoid presenting a large table, we have reported data only for selected majors but have included (i) all of those we identified earlier as requiring at least one mathematics course in their curricula as well as (ii) law and political science majors.

Our results in Table 3 indicate that only engineering and finance managers and professionals earn higher wages than economists. All others in these professions earn either similar or lower wages. 
Table 3 .

Wage Differentials of Selected Majors Compared to Economics Majors: Managers, Professionals, and Business Finance Professionals (\%)

\begin{tabular}{|c|c|c|}
\hline \multirow[b]{2}{*}{ Major } & \multicolumn{2}{|c|}{ Occupation } \\
\hline & $\begin{array}{c}\text { Managers and } \\
\text { Professionals }\end{array}$ & Business and Finance \\
\hline Engineering & $12.97^{* * *}$ & -4.24 \\
\hline Finance & $12.93^{* * *}$ & $9 \cdot 36^{* * *}$ \\
\hline Law (LLB, JD, BCL) & 8.69 & 0.18 \\
\hline Computer and information sciences & 5.46 & $-15 \cdot 31^{* * *}$ \\
\hline Philosophy & 3.4 & -13.01 \\
\hline Mathematics & 2.59 & $3 \cdot 5$ \\
\hline Accounting & 1.78 & -2.76 \\
\hline Health services & -6.36 & $-18.15^{* * *}$ \\
\hline Sociology & $-7.02^{*}$ & $-13.11^{* * *}$ \\
\hline Biology/biological sciences & $-9.25^{* *}$ & $-20.75^{* * *}$ \\
\hline Liberal arts and sciences & $-10.1^{* *}$ & $-19.25^{* * *}$ \\
\hline History & $-12.68 * * *$ & $-22.06^{* * *}$ \\
\hline Architecture & $-13 \cdot 38^{* * *}$ & $-16.73^{* * *}$ \\
\hline International relations and affairs & $-15.69^{* * *}$ & $-17.99^{* * *}$ \\
\hline Political science & -15.71 & $7 \cdot 57$ \\
\hline Psychology & $-15.83^{* * *}$ & $-16.3^{* * *}$ \\
\hline Geography & $-16.81^{* * *}$ & -4.94 \\
\hline English language and literature & $-17.82^{* * *}$ & $-21.98^{* * *}$ \\
\hline Agriculture & $-18.37^{* * *}$ & $-12.81^{* *}$ \\
\hline Foreign language and literature & $-18.74^{* * *}$ & $-24.59^{* * *}$ \\
\hline Business. admin. and management & $-19.53^{* * *}$ & $-20.39^{* * *}$ \\
\hline French language and literature & $-19.63^{*}$ & $-19.25^{* * *}$ \\
\hline Education & $-20.03^{* * *}$ & $-25.27^{* * *}$ \\
\hline
\end{tabular}

Notes: (1) The dependent variable is the natural log of the annual wage earned in the previous year, divided by the product of the number of weeks worked that year and the number of hours worked in the previous week, demeaned at each cell point. (2) Standard errors are robust and adjusted by cell. (3) One, two, and three asterisks indicate statistical significance at different levels of significance. (4) Economics is the excluded major. (4) All estimates are weighted to incorporate the sample stratification provided by the data. (5) For cell definitions, please see endnote 15.

Another useful comparison of labour-market performance across academic disciplines can be made by focusing on the career choices of majors. In their United States study, Allgood et al. (2011) found that economics and business degree holders tend to make similar labour-market decisions. One type of job economists and business majors are prepared to undertake, and on which data are available in the 2006 Canadian census, is that of business and finance professional. Skills acquired by those who major in accounting, business 
administration, and finance prepare them more directly to work as business and financial professionals. Comparing economists' wages with the wages of those in other disciplines who also work as business and finance professionals will shed some light on the relative preparedness of economists in jobs they are trained to do.

At the same time, graduates of other (non-economics and non-business) disciplines are also found working as business and finance professionals. This may be largely due to personal preference for self-employment or an innate ability to work as these types of professionals. In Table 3, we also compare economists' earnings with those of accounting, business administration, and finance professionals, and with the earnings of those whose majors were in other selected fields but who are working as business and finance professionals. . We find that except for finance majors who have direct training for these jobs, all others have wages similar to or lower than those of economists (as shown by the corresponding $t$ values).

The above comparisons were performed for undergraduate (bachelor's) degree holders. It is also important to analyze wage differences at graduate levels, for at least two reasons. First, the importance of a graduate-level education is increasingly recognized in education policy circles in Canada (Finnie \& Usher, 2007). An analysis of the comparative benefits of acquiring a graduate degree will be useful for students desiring to pursue higher education. Second, it could be argued that for some fields, such as the social sciences and humanities, the labour market is such that a bachelor's degree may not be the final entry-level postsecondary degree for job markets as often as it is for other majors, such as business, economics, and engineering. ${ }^{21}$ This may also be true for some programs in the physical sciences (astronomy, chemistry, physics, geology). For example, Black, et al (2003) found that about two-thirds of physics majors in the United States earned an advanced degree in 1993. If a significant portion of workers in a major pursue an advanced postsecondary degree, the wage gap between that major and an economics major-for workers who have only a bachelor's degree-could be misleading. Data on individuals' prior degrees are not available from the census. However, comparing the number of master's (graduate) degrees and bachelor's (undergraduate) degrees within a field can help address this issue to some extent.

Table 4 shows the number of workers who have a master's degree as their highest postsecondary education relative to the number of workers who have only a bachelor's. We report the data on only a few more popular majors to avoid presenting a longer table. ${ }^{22}$

Even though the numbers do not reflect demographic differences or indicate whether workers obtained their previous degree in the same field, the significant variation in the percentage of master's degree holders within each major is important to note. ${ }^{23}$ Students obtaining their undergraduate degree in international relations are the most likely to pursue a master's degree rather than join the labour force; in our sample, all of them had pursued a master's degree. On the other hand, those with undergraduate degrees in accounting, finance, and computer and information sciences are the least likely to do so. About one-sixth of economics undergraduates are likely to pursue a master's degree. These findings perhaps indicate the market demand for master's degrees in each discipline, relative to an undergraduate degree. 
Table 4.

Percentage of Workers with Master's Degree Relative to Number of Workers with (only) Bachelor's Degree, for Selected Majors

\begin{tabular}{lrlc}
\hline Major & $\%$ & & Major \\
\hline International relations and affairs & 100 & Education & 23 \\
Physical sciences & 61 & History & 23 \\
Biology/biological sciences & 51 & Economics & 21 \\
Archaeology & 45 & English language and literature & 20 \\
Philosophy & 44 & Political science & 19 \\
Business administration and manage- & 42 & Geography & 17 \\
ment & & & \\
Psychology & 32 & Computer and information sciences & 17 \\
Engineering & 28 & Finance & 15 \\
Anthropology & 25 & Sociology & 14 \\
Mathematics & 24 & Accounting & 12 \\
\hline
\end{tabular}

Table 5.

Wages in Selected Majors Relative to Economics, Undergraduates and Graduates

\begin{tabular}{|c|c|c|c|c|}
\hline \multirow[b]{2}{*}{ Major } & \multicolumn{2}{|c|}{ Undergraduate } & \multicolumn{2}{|c|}{ Graduate } \\
\hline & $\%$ & $\mathrm{t}$ & $\%$ & $\mathrm{t}$ \\
\hline Engineering & 16.84 & 14.01 & -8.89 & -3.24 \\
\hline Finance & 13.87 & 7.13 & 29.25 & $7 \cdot 35$ \\
\hline Health services & 13.82 & 11.05 & -21.68 & -7.38 \\
\hline Law (LLB, JD, BCL) & 13.2 & $7 \cdot 44$ & $-4 \cdot 35$ & -1.06 \\
\hline Accounting & 9.22 & 6.77 & $7 \cdot 3$ & 1.73 \\
\hline Computer and information sciences & 6.82 & 5.19 & -18.92 & $-5 \cdot 58$ \\
\hline Mathematics & 5.83 & 2.86 & -21.16 & -4.24 \\
\hline Business administration and management & 2.98 & 2.46 & 13.26 & 4.97 \\
\hline Business, other & -0.02 & -0.01 & -7.81 & -2.18 \\
\hline Criminology & -1.73 & -0.94 & -22.36 & -5.29 \\
\hline Marketing & -4.85 & -2.59 & 2.93 & 0.58 \\
\hline Education & -7.94 & -6.9 & -20.58 & -7.97 \\
\hline Political science & -8.6 & $-5 \cdot 35$ & -24.65 & -6.75 \\
\hline Architecture & -10.28 & -5.28 & -30.98 & -9.52 \\
\hline International relations and affairs & -12.53 & -2 & -22.05 & -3.8 \\
\hline Geography & -13.69 & -8.44 & -25.29 & -6.88 \\
\hline Biology/biological sciences & -14.33 & -9.48 & -38.01 & -11.92 \\
\hline Psychology & -15 & -11.25 & -31.72 & -11.31 \\
\hline Sociology & -15.92 & -10.41 & -36.05 & -8.34 \\
\hline
\end{tabular}




\begin{tabular}{lccccc}
\hline & \multicolumn{2}{c}{ Undergraduate } & & \multicolumn{2}{c}{ Graduate } \\
\cline { 2 - 3 } \cline { 5 - 6 } Major & $\%$ & $\mathrm{t}$ & & $\%$ & $\mathrm{t}$ \\
\hline Liberal arts and sciences & -16.42 & -10.27 & & -39.8 & -7.72 \\
Aeronautics/aviation/aerospace & -16.62 & -1.63 & & -47.93 & -2.05 \\
History & -16.97 & -11.03 & & -37.31 & -10.26 \\
English language and literature & -18.91 & -11.94 & & -39.68 & -11.26 \\
Agriculture & -19.44 & -9.77 & & -30.98 & -7.98 \\
Archaeology & -23.1 & -4.29 & & -43.2 & -6.86 \\
Philosophy & -23.44 & -7.94 & & -45.54 & -9.48 \\
Anthropology & -25.41 & -8.97 & & -59.21 & -5.41 \\
Visual and performing arts & -34.16 & -20.52 & & -60.8 & -15.98 \\
\hline
\end{tabular}

Notes: (1) The dependent variable is the natural log of the annual wage earned in the previous year, divided by the product of the number of weeks worked that year and the number of hours worked in the previous week, demeaned at each cell point for cell 1. (2) Standard errors are robust and adjusted by cell. (3) The numbers of observations are 204,222 and 60,185 for undergraduate and graduate, respectively, with cells having 150 or more workers. (4) Economics is the excluded major. (5) All estimates are weighted to incorporate the sample stratification provided by the data.

Table 5 compares wage gaps between economics and other majors for workers who only have an undergraduate (bachelor's) degree (data in the first two columns are copied from Table 2 and are ranked by the first column) and those who have a graduate degree. We also provide $t$ values for the statistical significance of the difference from economics. In 24 out of the 28 disciplines considered, the wage gap is negative in relation to economics, indicating that economics graduate degree holders earn more than those with degrees in other fields. The negative wage gaps at the graduate level are wider than at the undergraduate level, indicating a clear advantage to studying economics at the graduate level. Engineering majors, who had the most advantage over economics majors at the undergraduate level, lose this advantage at the graduate level (falling from 16.84 to $-8.89 \%$ ). Students pursuing graduate degrees in all business-related disciplines except for marketing increase their advantage over those who study economics at the graduate level, with finance degree holders gaining the most.

Another important aspect of comparative wage analysis is the analysis of wage growth over the life cycle. An individual's wage growth over the life cycle represents his/her adaptability to workplace requirements (Goyder, 2014). Differences in workplace adaptability may also be attributed to motivational and ability differences, in addition to other unobservable factors. Since our data are cross-sectional, we analyzed our wage data for different age cohorts in each discipline using the demographic controls that were adopted in Table 2. Table 6 reports our results for undergraduate degree holders' wage gaps with respect to economics in selected fields, classified into six age groups for individuals with the demographic characteristics that were isolated in cell 1 of Table 2. As before, a positive gap means higher wages in the discipline than in economics ("advantaged discipline"), and a negative gap means lower wages ("disadvantaged discipline"). Data in Table 6 are ranked by the first column. 
Table 6.

Wages Relative to Economics Majors (\%) with Bachelor's Degree, by Age Cohorts

\begin{tabular}{|c|c|c|c|c|c|c|}
\hline Majors & -30 & $30-35$ & $35-40$ & $40-45$ & $45-50$ & $50+$ \\
\hline Health services & 33.83 & 20.29 & 9.05 & 2.27 & 1.19 & 12.36 \\
\hline Engineering & 23.92 & 19.84 & 12.67 & 11.98 & 10.76 & 22.77 \\
\hline Accounting & 14.67 & 12.72 & 10.62 & 3.89 & 0.82 & 11.42 \\
\hline Computer and information sciences & $14 \cdot 51$ & 10.4 & $5 \cdot 59$ & 4.78 & 3.94 & $5 \cdot 93$ \\
\hline Mathematics & 13.81 & 10.61 & 1.93 & 1.64 & -0.9 & 12.43 \\
\hline Finance & 12.45 & 18.42 & 14.28 & 16.83 & 11.16 & 6.87 \\
\hline Business administration and management & 9.85 & 6.41 & 0.93 & -1.25 & -2.7 & 3.45 \\
\hline Law (LLB, JD, BCL) & 9.72 & 15.08 & 15.66 & 11.87 & $7 \cdot 44$ & 22.88 \\
\hline Human services & 6.75 & -5.28 & -18.75 & -19.74 & $-23 \cdot 3$ & -8.41 \\
\hline Education & 6.08 & $-4 \cdot 34$ & -11.61 & -14.53 & -17.4 & -6.21 \\
\hline Business, other & 4.33 & 2.75 & 2.52 & -2.55 & -13.12 & $3 \cdot 51$ \\
\hline Criminology & 2.77 & 1.66 & -2.82 & $-3 \cdot 48$ & -3.11 & -7.87 \\
\hline Marketing & -1.15 & 1.89 & -2.93 & -6.52 & -19.33 & 22.01 \\
\hline Architecture & -1.91 & -9.62 & -18.57 & $-13 \cdot 57$ & -8.57 & $-3 \cdot 94$ \\
\hline Political science & -2.87 & -0.85 & $-5 \cdot 32$ & -19.2 & $-15 \cdot 4$ & $-4 \cdot 74$ \\
\hline Communication studies & -3.18 & $-5 \cdot 57$ & -14.01 & -15.68 & -23.5 & -8.52 \\
\hline Archaeology & -4.97 & -12.68 & -26.97 & -52.17 & -37.97 & -9.24 \\
\hline French language and literature & -5.16 & -12.57 & $-25 \cdot 39$ & -18.22 & -30.03 & 5.68 \\
\hline Foreign language and literature & -6.21 & -9.71 & -20.37 & $-27 \cdot 4$ & -24.16 & -10.54 \\
\hline Agriculture & -6.24 & $-17 \cdot 54$ & -22.6 & -27.86 & $-25 \cdot 77$ & -19.02 \\
\hline Geography & -6.27 & -6.35 & -19.23 & -17.84 & -19.09 & -9.43 \\
\hline Psychology & -6.73 & -6.13 & -17.67 & $-23 \cdot 41$ & $-24 \cdot 72$ & -11.32 \\
\hline Sociology & -8.48 & -8.96 & -14.69 & -21.4 & -26.18 & -18.15 \\
\hline Liberal arts and sciences & -11.04 & -18.23 & -16.47 & -20 & -21.02 & -10.12 \\
\hline History & -11.71 & -12.99 & -16.23 & -26.31 & -24.87 & -9.33 \\
\hline Anthropology & -14.02 & -31.45 & -23.18 & -26.17 & -37.96 & -11.71 \\
\hline English language and literature & $-15 \cdot 31$ & $-17 \cdot 41$ & -20.64 & -25.67 & -21.21 & -7.13 \\
\hline Biology/biological sciences & -16.41 & $-5 \cdot 72$ & -9.76 & -14.49 & -24.12 & -6 \\
\hline Philosophy & -23.55 & -17.25 & -20.81 & -34.94 & -37.69 & -3.42 \\
\hline Visual and performing arts & -31.58 & -32.57 & -34.59 & -34.79 & -41.41 & -26.45 \\
\hline
\end{tabular}

Notes: (1) The dependent variable is the natural log of the annual wage earned in the previous year, divided by the product of the number of weeks worked that year and the number of hours worked in the previous week, demeaned at each cell point for cell 1. (2) Standard errors are robust and adjusted by cell. (3) Starting from the first column, the numbers of observations are: 44,$770 ; 41,752 ; 37,387 ; 35,143 ; 30,207$; and 24,134, respectively. (4) Economics is the excluded major. (5) All estimates are weighted to incorporate the sample stratification provided by the data. 
In most cases, for those who major in advantaged fields, their wage gap in comparison with economics majors diminishes until they reach age 50; the wage gap rises in favour of economists over those who major in disadvantaged fields. When we compare economics with fields of study that have a math requirement, we find that the advantaged fields have significantly higher entry wages, but the wage gap diminishes rapidly when they cross 40 years of age, with the exception of engineering and finance degree holders, for whom the gap closes at a much slower pace. This result indicates that those with economics degrees are faster learners on the job, which perhaps is evidence that they have better motivation and greater ability than other degree holders. For graduates in the disadvantaged disciplines, a narrowing of the gap takes place after they reach 50 years of age, whereas a widening of the gap occurs for those in this age group in the advantaged fields. Rising wage gaps in fields such as computer and information sciences, accounting, health, etc. after the 50-year threshold could reflect the graduates' "premium" status as senior members of professional organizations. ${ }^{24}$ These life-cycle results appear to contradict Goyder (2014), whose analysis based on the longitudinal Survey of Labour and Income Dynamics (2005-2010) showed that the incomes of graduates of Canadian liberal arts undergraduate programs, which in the 1990 s used to catch up with those of graduates from applied programs, no longer did. However, he did not analyze detailed fields of study.

\section{Conclusions}

We analyzed 2006 census micro-data to compare the wages of economics degree holders with those in 49 other fields of study. Undergraduate degree holders in economics rank sixth among wage earners in 50 major fields. This ranking falls to ninth when demographic controls are introduced. The unemployment rates among economics majors are among the lowest and similar to those who major in engineering, biological sciences, physics, and mathematics. Those who hold a graduate degree in economics face a narrower earnings gap with respect to fields in which wage earning is higher, and a wider gap with respect to the remaining fields. Finally, once they are on the job, economics majors experience faster growth in earnings compared to those with degrees in other fields.

An important contribution of this paper is its analysis of the effects of some unobservable characteristics of workers on their wages. We isolated 14 fields of study that may be considered comparable in terms of preparing students to meet labour-market demand for analytical and mathematical abilities; we found that economists rank in the middle and that the average differential between the wages of these degree holders and economists' wages is small. The same conclusion holds for economics degree holders working as middle or senior managers in an organization. When we analyzed the wages of those who work as business and finance professionals, we found that only finance majors perform better than economists. Finally, their faster growth in earnings over their career life cycle is another indication of their having better labour-market preparation than those holding degrees in other comparable fields of study, and of their having higher motivation and greater ability to adapt to workplace requirements. Our incorporation of ability and motivation factors is indirect but serves as a basis for other studies on this topic.

The overall personal economic benefits of obtaining an economics degree are consistent with those found for Australia by Dally and Lewis (2010) and for the United States by Allgood et al. (2011), Black et al. (2003), and Freeman (1999). Two other Canadian 
studies have also reported data that can be used to compare the earning of economics majors with others' earnings. One study, Finnie and Frennette (2003), which used 1995 earning data based on the National Graduate Survey, found that economics degree holders ranked in the middle when compared with some broad academic disciplines. Another study, Stark (2007), which used 1996 census data on earnings and also computed the costs of acquiring degrees in various fields, found that the rate of return on an economics degree in 1995 was comparable to that in six broad disciplines at the bachelor's level, and was exceeded significantly only by commerce, management, and business administration at the master's level and by agriculture and biology at the doctoral level. However, variations in these results existed within each discipline. Previous studies on this topic (Rathje \& Emery, 2002; Stager, 1996; Vaillancourt, 1995; Vaillancourt \& Bourdeau-Primeau, 2002) have also analyzed rates of return across broad academic disciplines. The present study is the first in Canadian higher education literature to focus on the labour-market performance of economics degree holders in comparison with those holding degrees in other fields of study. We have used more recent data and more variables to control for demographic characteristics across individuals than did previous studies. Hence, we believe this study serves as a foundation for subsequent analyses of other fields of study.

The positive economic benefit to studying economics demonstrates the market value of analytical tools developed in economics courses. This may not be immediately obvious to students, either because of the emphasis on formalization and the use of mathematics or because of their lack of preparedness for the fields of study that require mathematical skills to build analytical skills. A future study could investigate this possibility. By demonstrating a high market reward for studying economics in Canada, our research highlights the need for a greater public policy focus on developing mathematical skills among students enrolled at pre-university levels of education, as a prerequisite for acquiring the analytical skills that are demanded in labour markets.

\section{Notes}

1. Millmow and Tuck (2010) view business and law degrees as competing with economics degrees in Australia, while Seigfried and Round (2001) view business degrees as competing with economics degrees in Australia, Canada, Germany, and the United States.

2. Our Figure 1 data indicate that overall, enrolments in law and business degrees rose by 20\% and 40\%, respectively, between 1992 and 2008, while enrolments in economics stagnated. Data published by the Association of Universities and Colleges of Canada (2011, Figures 1 and 5) indicate university student enrolments in Canada rose by about $107 \%$ during the same period.

3. Goyder (2014) discusses the socioeconomic characteristics of students enrolled in liberal arts programs in Canadian universities.

4. Although the IAAC did not test incoming university students, Dion (2014) reports concerns raised by university faculty regarding declining mathematical skills among incoming students.

5. Of course, social externalities generated by higher education remain important for the consideration of public funding of higher education. 
6. Indeed, our interest in conducting this study arose when we were proposing to offer a graduate degree program in applied economics at our university. The proposal had to be defended not only within but also outside the university community.

7. Details of the coding can be found on the following Statistics Canada website: http:// www23.statcan.gc.ca:81/imdb/p3VD.pl?Function=getVDPage $1 \& d b=i m d b \& d i s=2 \& a$ $\mathrm{dm}=8 \& \mathrm{TVD}=127939$

8. Bachelor of Law (LLB), Juris Doctor (JD), and Bachelor of Civil Law (BCL) are all undergraduate degrees. Students who have completed two years of university credits are eligible to apply to study for these degrees. However, most Canadian students pursuing these degrees also possess another undergraduate degree.

9. The correlation coefficient is -0.46 .

10. This finding somewhat corroborates that of Freeman (1999), who reports that at the $\mathrm{PhD}$ level, economists in the United States enjoy a better job market than do PhD holders in two of the most important scientific areas: mathematics and physics.

11. The correlation coefficient between the wage rate and the female composition of a discipline is about -0.48 .

12. It should be noted, however, that the law degree (LLB) may not be comparable to other bachelor's degrees, since, in most cases, it requires a prior undergraduate degree (Ostrovsky \& Frenette, 2014). However, the census data do not distinguish law degrees from other undergraduate degrees.

13. Political science students also obtain some training in economics, as understanding the interactions between economics and political systems is part of their curriculum; they may also develop some quantitative tools of analysis. In addition, political science students may compete in labour markets with some economics students.

14. Thirteen visible minority types (Chinese, South Asian, Black, Filipino, Latin American, Southeast Asian, Arab, West Asian, Korean, Japanese, visible minority n.i.e., multiple visible minority, Aboriginal), one non-visible minority, and one not applicable. Given the importance of visible minority groups in Canadian labour markets, we also considered two more variations of visible minority groups in cells 2 and 3 and performed a test to gauge the sensitivity of the results to different cell definitions. The results (presented in the appendix to this paper) show no sensitivity to cell definitions.

15. Although the test results show that the order of the study fields in terms of their wage differentials from economics is not statistically sensitive to cell sizes, their wage differentials themselves are. This sensitivity disappears when the cell size is set to 150 or above. Black et al. (2003) used the same sensitivity test and set their cell size to 300.

16. In our choice of universities, we were mindful of achieving Canada-wide representation and taking into account variations in size. However, the ease of obtaining information restricted our choice to only 16 . The undergraduate calendars were reviewed to determine which fields of study, at all of these universities, required students to take at least one course in mathematics.

17. Comparisons of economics majors with business majors are also meaningful because of the United States study, mentioned earlier, by Allgood et al. (2011), which found that economics and business majors tend to make similar labour market decisions.

18. Using data for public universities in the United States, Allgood et al. (2011) found that business majors earned less than economics majors. 
19. Our long list of disciplines in Table 2 is useful, considering that economics departments in Canadian universities are spread over faculties of Arts, Business, and Science.

20. The latest matrix can be found on the HRSDC website at: http://www5.hrsdc.gc.ca/ noc/english/noc/2011/html/Matrix.html. The 2006 census used 2001 occupational codes that are similar to the broad 2011 codes.

21. However, Allgood et al. (2011) found in four major, public United States universities that the economics coursework and majors in economics were negatively related to completing graduate degrees, except the MBA.

22. A table with all 50 disciplines can be provided upon request.

23. The census provides CIP code information only for the highest degree obtained by an individual and not separately for undergraduate and graduate degrees.

24. Estimates of wage age profiles indicate that the wages of economists rise until they reach 50 years of age; among disciplines with math requirements, only health services professions fare better, with the peak occurring at age 56 .

\section{Acknowledgements}

We thank professors David Gray and Herbert Grubel, along with the two anonymous reviewers of this paper, and the participants in a session at the 2013 Canadian Economics Association meeting for their valuable comments on earlier versions of this paper. Responsibility for any shortcomings remains with us.

\section{References}

Allgood, S., Bosshardt, W., \& Wibert van der Klaauw, H. (2011). Economics coursework and the long-term behavior and experience of college graduates in labor markets and personal finance. Economic Inquiry, 49(3), 771-794.

American Management Association. 2013. Companies see need to build analytical skills in their organizations: A study of analytical skills in the workplace (AMA staff writer). http://www.amanet.org/training/articles/Companies-See-Need-to-Build-AnalyticalSkills-in-Their-Organizations.aspx

Association of Universities and Colleges of Canada. (2011). Trends in higher education: Volume 1 - enrolment. Retrieved from http://www.aucc.ca/wp-content/ uploads/2011/05/trends-2011-vol1-enrolment-e.pdf

Black, D., Sanders, S., \& Taylor, L. (2003). The economic reward for studying economics. Economic Inquiry, 41(3), 365-377.

Brahim, B., \& Montmarquette, C. (2007). Choice of fields of study of Canadian university graduates: The role of gender and their parents' education. IZA Discussion Paper No. 2552. Retrieved from http://ftp.iza.org/dp2552.pdf

Broder, M. (2013, April 7). Motivation in the workplace for optimal results is not a "one size fits all” implementation. Retrieved from http://www.huffingtonpost.com/michael-sbroder-phd/employee-motivation-productivity-_b_2615208.html

Dally, A., \& Lewis P. (2010). The private rate of return to an economics degree in Australia. Economics Papers, 29(3), 353-364. 
Dion, N. (2014, September 25). Emphasizing numeracy as an essential skill. Toronto, ON: Higher Education Quality Council of Ontario. Retrieved from http://www.heqco.ca/ SiteCollectionDocuments/Numeracy\%2oENG.pdf

Espinosa, M., Rondon, C., \& Romero, M. (2012). The use of mathematics in economics and its effect on a scholar's academic career. Munich Personal RePEc Archive. Retrieved from http://mpra.ub.uni-muenchen.de/41363/

Finnie, R., \& Frenette, M. (2003). Earning differences by major field of study: Evidence from three cohorts of recent Canadian graduates. Economics of Education Review, 22, 179-192.

Finnie, R., \& Usher, A. (2007). Room at the top: Strategies for increasing the number of graduate students in Canada. C.D. Howe Institute Commentary, 245, 1-26. Retrieved from http://www.cdhowe.org/pdf/commentary_245.pdf

Freeman, R. B. (1999). It's better being an economist (but don't tell anyone). Journal of Economic Perspectives, 13(3), 139-145.

Goyder, J. (2014). Liberal arts catch-up revisited. Canadian Journal of Higher Education, 44(2), 30-48.

Grubel, H., \& Boland, L. (1986). On the efficient use of mathematics in economics: Some theory, facts and results of an opinion survey. Kyklos, 39(3), 419-442.

Hango, D. (2014, November 14). University graduates with lower levels of numeracy and literacy skills. Statistics Canada Catalogue No. 75-006-X. Retrieved from http:// www.statcan.gc.ca/pub/75-006-x/2014001/article/14094-eng.pdf

Hoyles, C., Wolf, A., Molyneux-Hodgson, S., \& Kent, P. (2002, June). Mathematical skills in the workplace: Final report to the Science, Technology and Mathematics Council. London: Institute of Education, University of London. Retrieved from http://eprints.ioe. ac.uk/1565/

Lewis, P., Daly, A., \& Fleming, D. (2004). Why study economics? The private rate of return to an economics degree. CLMR Discussion Paper Series 04/5. Retrieved from https://business.curtin.edu.au/local/docs/2004.5_WhyStudyEcons.pdf

Millmow, A., \& Bookallil, C. (2006). Girls and economics: An unlikely coupling. Economic Papers, 25(3), 221-234. doi:10.1111/j.1759-3441.2006.tbo0397.x

Millmow, A., \& Tuck, J. (2011). Did the global financial crisis have any impact on economics degree enrolments? Economic Papers, 30(4), 557-567. doi:10.1111/j.17593441.2011.00141.X

Oatrovsky, Y., \& Frenette, M. (2014). The cumulative earnings of post-graduates over 20 years: Results by field of study. Statistics Canada Catalogue No. 11-626-x. Retrieved from http://www.statcan.gc.ca/pub/11-626-x/11-626-x2014040-eng.htm

Rathje, A., \& Emery, J. (2002). Returns to university education in Canada using new estimates of program costs. In D. E. W. Laidler (Ed.), Renovating the ivory tower: Canadian universities and the knowledge economy (pp. 241-264). Toronto, ON: C.D. Howe Institute. 
Siegfried, J., \& Round, D. (2001). International trends in economics degrees during the 1990s. Journal of Economic Education, 33(3), 203-218.

Snowdon, K. (2005). Without a roadmap: Government funding and regulation of Canada's universities and colleges. Research Report W/31 Work Network. Ottawa, ON: Canadian Policy Research Networks Inc. Retrieved from http://www.cprn.org/ documents/40781_en.pdf

Stager, David, (1996). 'Returns to Investment in Ontario University Education, 19601990, and Implications for Tuition Fee Policy,' Canadian Journal of Higher Education 26, no. 2.

Stark, A. 2007. Which fields pay, which fields don't? An examination of the returns to university education in Canada by detailed field of study. Department of Finance Government of Canada (Working Paper 2007-03).

Vaillancourt, F. (1995). The private and total returns to education in Canada, 1985. Canadian Journal of Economics, 28(3), 532-554.

Vaillancourt, F., \& Bourdeau-Primeau, S. (2002). The returns to university education in Canada, 1990 and 1995. In. D. E. W. Laidler (Ed.), Renovating the ivory tower: Canadian universities and the knowledge economy (pp. 215-240). Toronto, ON: C.D. Howe Institute.

\section{Contact Information}

Ather H. Akbari

Saint Mary's University

Ather.Akbari@smu.ca

Ather H. Akbari is associated with the Economics Department at Saint Mary's University, in Halifax, Canada. He teaches labour economics, microeconomics, and managerial economics. His research interests are in the areas of the economics of immigration, education, health, and development. Akbari has received several research grants from Canada's federal and provincial governments. His research on the economics of immigration has appeared in various scholarly journals as well as in national and international news media.

Yigit Aydede is associated with the Economics Department at Saint Mary's University, in Halifax, Canada. He teaches public finance, econometrics, and environmental economics. He has worked at the Networks Financial Institute, Indiana State University, where as a research fellow he published several working papers in the area of social security. His research interests are in the fields of the economics of aging, the economics of immigration, social security, and applied microeconomics. His present research, which investigates generational fairness in public policies and the effects of immigration on local markets and population flows, has been published in various scholarly journals. 